\title{
Resurrection Appearances of Jesus as After-Death Communication
}

\author{
Ken R. Vincent, Ed.D. \\ Houston, TX
}

\begin{abstract}
Scientific research into after-death communication began at the end of the 19th century. During this early period, psychical researcher James Hyslop and theologian Rudolph Otto wrote about the resurrection of Jesus as a visionary / spiritual experience - as opposed to a physical, "bodily" resurrection. More recently, liberal theologians and religious experience researchers have also favored this view. The purpose of this article is to: (a) underscore the fact that the resurrection of Jesus as an after-death communication is solidly based in the only first-hand account of Paul and the verified secondary accounts of Peter and James (I Cor 15:5-8) in the New Testament, and (b) demonstrate that, although a physical resurrection is implied by the Gospel writers because of the empty tomb, the appearance stories of Jesus are more in accord with the phenomenology of modern after-death communications by Jesus, other divine figures, and ordinary people.
\end{abstract}

KEY WORDS: resurrection, Jesus, after-death communication, visions, apparitions

Easter is a day when Christians celebrate the resurrection of Jesus; it is an occasion much more significant than their celebration of Jesus' birth at Christmas. Resurrection literally means "rising from the dead and coming back to life." Emory University professor Luke Timothy Johnson (1998, p. 11) has gone so far as to call the resurrection the "grounding for the entire Christian life."

Was Jesus raised in a spiritual body or a physical body? In most traditional Christian churches, listeners will hear of a physical, bodily

Ken R. Vincent, Ed.D., is a writer and religious experience researcher who is retired from teaching psychology at Houston Community College. He has over 150 publications in the areas of psychology and religion. Correspondence regarding this article should be sent to Dr. Vincent at 1701 Hermann Dr. \#2503, Houston, TX 77004; email: professorvincent@yahoo.com. 
resurrection; in fact, a 2005 Newsweek (2009) poll found that half of Americans believe in a physical resurrection. This inference is based on the stories of Easter morning in the four Gospels, which relate that Jesus' body was not in the burial tomb when Mary Magdalene (present in all Gospel accounts), accompanied by one or more women (in other Gospel accounts), arrived there. This view has been perpetuated by millions of Christians since the 4 th century who learned to recite from the Apostle's Creed the phrase, "... resurrection of the body and life everlasting."

Interestingly, the same 2005 Newsweek poll (2009) showed onethird of Americans think that Jesus' resurrection was a spiritual one! My purpose is to present this view as the authentic one, first, because it is more consistent with the New Testament accounts, and second, because it is most compatible with scientific research into spiritually transformative experiences over the past 125 years. As a religious experience researcher myself, I am convinced that mystical religious experiences are a normal part of a healthy, non-psychotic human life and that the religious experiences of Jesus represent the same phenomena as those of all people, despite time or culture.

In the early 20th century, philosopher and psychical researcher James Hyslop (1908, p. 383) and theologian Rudolph Otto (1950, pp. 222-229) began to see the resurrection of Jesus as a visionary / spiritual experience-what is now called an after-death communication (ADC). More recently, liberal theologians (Funk \& the Jesus Seminar, 1998, pp. 449-495) and religious experience researchers (Wiebe, 1997, pp. 106-107; 121; 212-222) have favored a spiritual resurrection over a physical resurrection.

"An after-death communication (ADC) is a spiritual experience that occurs when someone is connected directly and spontaneously by a deceased family member or friend" (Guggenheim \& Guggenheim, 1996, p 15). Guggenheim and Guggenheim (1996) acknowledged that Jesus and his mother Mary are the best-known ADCs but elected not to make the comparison for fear of offending Christians (p. 11). Obviously, I have included Jesus, his mother Mary, and other divine beings, as that is the purpose of this paper.

\section{Paul}

In the New Testament, Paul has the distinction of being the earliest writer, as well as the only writer to give a first-person account of Je- 
sus' resurrection. Paul's ADC with Jesus occurred about four years after Jesus' death, and he wrote about this experience about 20 years later (White, 2004, pp. 150, 172). Paul was not a follower during Jesus' lifetime but became one of the most influential Apostles, having enormous influence over the direction of early Christianity, especially in the West. Paul's letters also provide the only verified second-hand reports of the resurrection-those of Peter, an early disciple of Jesus, and James, the brother of Jesus, whom Paul had met. These are Paul's own words:

He (Jesus) appeared to Cephas (Peter) and to the Twelve. Then he appeared to more than 500 brothers and sisters at one time, most of whom are still alive, though some have died. Then he appeared to James, then to all the Apostles. Last of all, as one untimely born, he appeared also to me. (I Cor 15:5-8 NRSV)

About 80 years after the death of Jesus (White, 2004, p. 252), Luke -widely accepted to be the author of the Acts of the Apostles-tried to suggest that Paul's experience of Jesus was somehow different from the appearances of Jesus to his former earthly companions. Luke clearly explained that he was a compiler of stories that were handed down to him (Lk 1:1-3). Luke's accounts of Jesus appearing to Paul in the Acts of the Apostles (Acts 9:3-9; 22:4-16; 26:9-18) are somewhat contradictory, but in all three accounts Paul saw a "light from heaven" and heard the voice of Jesus. Although this experience sounds like a modern ADC (Fox, 2008, p 41-43), it does not square with Paul's own first-person account that (a) he had "seen Jesus our Lord" (I Cor 9:1 NRSV), (b) "God . . . was pleased to reveal his Son to me" (Gal 1:15-16), and (c) "he [Jesus] appeared also to me" (I Cor 15:8b). Paul stated definitely that his ADC from Jesus was identical to that of the others (I Cor 15:5-8 NRSV). Paul was equally adamant that resurrected bodies are spiritual in nature: "It is sown in a physical body, it is raised a spiritual body" (I Cor 15:44 NRSV). He emphasized the point that "flesh and blood cannot inherit the Kingdom of God nor does the perishable inherit the imperishable" (I Cor 15:50 NRSV).

In other words, Paul knew nothing about a physical resurrection of Jesus. Many years after Paul's letters were written, the writers of the Gospels implied a physical resurrection of Jesus because of the empty tomb. In reality, the empty tomb adds nothing (Funk et al., 1998, p. 463), as no one saw Jesus revive and walk out of the tomb, and no one saw anyone remove Jesus' body as was later claimed (Matt 28:11-15). 


\section{First Letter of Peter}

Written about 50-65 years after Jesus' death under the name of Peter (White, 2004, p. 274), the First Letter of Peter also presents a spiritual resurrection. It states: "He [Christ] was put to death in the flesh but made alive in the Spirit" (I Peter 3:18b NRSV).

\section{Four Gospels}

The Gospel of Mark is the earliest, written about 40-45 years after Jesus' death (White, 2004, p. 233). Its original ending had no resurrection appearances but ended with the mystery of an empty tomb. Much later, resurrection stories were added to Mark that appear to be a synopsis of those in the other three Gospels (Funk et al., 1998, pp. 465-467).

The Gospel of Matthew, written 50-60 years after the death of Jesus (White, 2004, p. 244), has a pre-resurrection story at the time of Jesus' death stating that "the tombs also were opened, and many bodies of the saints who had fallen asleep were raised. After his resurrection they came out of the tombs and entered the holy city and appeared to many" (Matt 27:52-53 NRSV). The writer of Matthew had Jesus appear first to Mary Magdalene and the "other Mary" who took hold of his feet and worshiped him. The second ADC of Jesus was placed in Galilee where he appeared to his 11 disciples: "When they saw him, they worshipped him; but some doubted" [emphasis added] (Matt 28:9-10,17 NRSV).

The Gospel of Luke, written 60-70 years after the death of Jesus (White, 2004, p. 252), told of two of Jesus' Apostles meeting Jesus while walking on the road to Emmaus. Luke said that their "eyes were kept from recognizing him." After talking to Jesus and inviting him to supper, he broke bread, they recognized him, and he vanished from their sight. Later he appeared to the Apostles and asked them to touch him. Luke reported that Jesus stood among the disciples suddenly, saying, "Peace be with you," and the disciples were startled and terrified and "thought they were seeing a ghost." Then he ate a piece of fish (Lk 24).

The Gospel of John, written 65-90 years after the death of Jesus (White, 2004, p. 310), includes many other appearance stories. When Jesus appeared to Mary Magdalene, she did not recognize him until he spoke her name. Unlike the Gospel of Matthew in which Mary Magdalene touched Jesus, Jesus told Mary not to touch him. Jesus 
later appeared suddenly in a locked room to all the Apostles but Thomas. Because Thomas doubted their story, Jesus appeared again to the Apostles while Thomas was present and asked Thomas to touch the wound in his side. Later, Jesus appeared to seven Apostles who were fishing in the Sea of Tiberias; they hadn't caught anything, and Jesus-using his psychic ability-told them where to cast their nets. They then recognized him, and Jesus served them fish and bread (Jn 20;21).

\section{Acts of the Apostles}

The Acts of the Apostles was written 80 years after Jesus' death (White, 2004, p. 252). It states that Jesus appeared to people for 40 days, after which he ascended to Heaven on the Day of Pentecost (Acts 1). (This is curious because there is a previous Ascension story in Luke [Lk 24:50-53].)

\section{Ascension}

What is the purpose of placing the Ascension story 40 days after Easter, if Jesus was raised up to God on Easter Day? A problem exists only for those advocating a "physical body" scenario. Using Paul's view-which is the modern view-that Jesus' resurrection was an ADC, no explanation is needed because spiritual beings can appear at will from the afterlife whether the percipient is an ancient who viewed heaven as "above the earth" or a modern who views heaven as "another reality."

In summary, I have identified nine categories of Jesus' resurrection appearances in the accounts of the New Testament:

1. He appeared to individuals.

2. He appeared to small groups and large groups.

3. Sometimes Jesus' former friends did not recognize him.

4. Sometimes people touched Jesus.

5. In one account, Mary Magdalene was asked not to touch Jesus.

6. Jesus appeared and disappeared instantly; he walked through locked doors.

7. Jesus broke bread, served breakfast, and ate!

8. Jesus used his psychic powers - to predict where to catch fish.

9. Jesus converted people (like St. Paul).

All of these behaviors exhibited by the resurrected Jesus have been reported throughout history. Turning now to modern accounts of after- 
death appearances of Jesus, other divine figures, and ordinary people, such accounts demonstrate that all of the above nine behaviors exhibited in the New Testament are present in modern-day accounts by non-psychotic individuals and verified by modern religious experience researchers.

1. Individuals. The following is a 20 th century account by a British woman:

"All at once I felt someone near me, a Presence entered this little room of which I became immediately conscious. This feeling or second sense could be very frightening, but I was not afraid or alarmed. I saw in my mind our Blessed Saviour, and the picture of Him has never left me." (Maxwell \& Tschudin, 2005, p. 115)

2. Small and large groups. Post-death visions seen by more than one person-whether the vision is a religious figure or an ordinary person-are well-documented (Guggenheim \& Guggenheim, 1996, pp. 285-300; Kalish \& Reynolds, 1973; Myers, 1903, pp. 62-65; Wiebe, 1997, pp. 15-88). In a study of 434 residents of Los Angeles, including persons of Black, European, Japanese, and Mexican origins, "slightly over $2 \%$ reported post-death encounters that were part of the reality of another person present at the time" (Kalish \& Reynolds, 1973, p. 219). In a study of 400 mystical experiences that involved light, $2.5 \%$ involved multiple witnesses (Fox, 2008, p. 64).

In the following account, a woman and her husband-to-be shared a vision of Jesus while they were walking in the moonlight:

"Then the figure emerged, a most brilliant sight. We were both speechless, but not afraid, it was so beautiful. The figure, Jesus Christ, glided onto the centre of the road while we were on rough pavement . . We still remember every detail, but our views on religion have deepened; although, still, we are not too religious." (Maxwell \& Tschudin, 2005, pp. 77-78)

3. Not recognized. On the Road to Emmaus, "their eyes were kept from recognizing him" (Lk 24:16). Modern people have also experienced visions of Jesus in disguise (Migliore, 2009, pp. 137-139).

The following is a woman's vision of Jesus while she was meditating:

"I went forward, alone, toward an old man who stood at the very end of the rose-covered arches. I stopped before him. He asked me if ministry was what I really wanted. I replied affirmatively. He then used his thumb to make the sign of the cross on my forehead, my hands, my feet, my lips, and over my heart-in that order. Then he said, 
'Go in peace.' I wondered who he was. He looked at me with sad eyes and said, 'Don't you know me?' With his words, the illusion of the old man fell away, and I realized that he was Christ" (Sparrow, 1995, pp. 150-151).

4. Touching. In one account, a woman touches Jesus' hair (Sparrow, 1995, p. 32). Ordinary people also come back from the dead, and their loved ones report having touched them:

"After the sudden death of my husband about nine years ago, I had
several experiences, which proved to me that there is a life after death.
I am not a Spiritualist, nor a Churchgoer, but I try to follow Jesus,
and I am a great believer in meditation, as a way to God. After his
passing, I both saw and spoke to my husband and held his hand. This
hand was strong and not at all ghost-like, nor was his appearance. I
was alone at the time, so no medium there to act as a link. Probably
this is not a detail to prove God's existence, but to me, it indeed did."
(Hardy, 1997, p. 47)

John Hick (2006, p. 34) noted that other holy figures have appeared to their followers and provided an account of a young Hindu embracing Lord Krishna. In a study of 293 widows and widowers, Dewi Rees found not only that slightly less than half of them had contact with their deceased spouse but also that $2.7 \%$ actually touched them (Fenwick \& Fenwick, 2008, p. 121).

5. Not touching. This next modern visionary account is of a woman's dead husband:

"Not long afterwards, I awoke shaking violently from head to foot. He had appeared to me, radiant, smiling, his usual happy self. I had impulsively gone forward to greet him, saying, 'Do you know-I've just been having a dream.' Something stopped me before I touched himhe was there, completely himself, but of a different 'substance.' I drew back, as it were, looking in through a frame, to another dimension. I stopped, and said to him, 'I know, I understand.' This experience, following his death, has given me great comfort. .." (Hardy, 1997, p. 47).

6. Vanishing, reappearing, walking through solids. Modern visions of Jesus include his appearance to Charles Finney, a 19th century minister:

"There was no fire or light in the room; nevertheless, it appeared as if it were perfectly light. As I went in and shut the door, it seemed as if I met the Lord Jesus Christ face to face. It did not occur to me that it was a wholly mental state; it seemed that I saw him as I would see any other man.” (Bucke, 1991, p. 288) 
7. Food. In Visions of Jesus, Phillip Wiebe (1997, p. 43) recounted a modern story of Jesus offering wine.

In his book, Long March to Freedom, Tom Hargrove (1995, pp. 277, 334) described his experience of being held captive by the FARC in Colombia. In the book, Tom briefly described his vision of Jesus, and he was kind enough to send me an expanded account of this encounter:

Terribly depressed, I went to El Templo on May 26. Alone by my broken cross of bamboo, I started to cry. Then something strange happened. Was it a religious experience or a hunger-induced hallucination? I don't know. But I thought I saw an ephemeral, bearded man walking from the woods to El Templo. I described him in my diary as having a Kris Kristofferson beard, and wearing jeans, red plaid flannel shirt, high leather boots - the lace-up kind. The man came closer, and his face seemed exactly that of the stereotyped Jesus whose portrait hangs on Sunday School walls. He laughed, and told me to sit on a log. I'm sorry I was crying, I said. 'You can cry here whenever you wish,' the man replied. Then somehow, he opened a liter bottle of Gallo Hearty Burgundy and poured two crystal goblets of red wine. We drank, then he said he must leave, but maybe we could visit again. He added (I wrote in my diary), but I might include him more when I'm having fun after I leave here. That ephemeral man walked back into the forest, and I was alone again. I had never before and have never again had such an experience. What made it still stranger was (that) I have never remotely thought of Jesus dressed in jeans, red flannel shirt, and lumber-jack boots. (Tom Hargrove, personal communication, August 23, 2002)

When I questioned Tom, he said:

If Jesus had been dressed in robes and sandals, I would be less inclined to think it's real. It's the only story that I have a hard time telling. It didn't change me, but it sure enough impressed me. I guess it did make a big difference to me. (Tom Hargrove, personal communication, August 23, 2002)

8. Psychic powers. In this example, Jesus' Mother Mary also appears to have had psychic powers. After giving a talk on the scientific study of the paranormal a few years ago, a colleague (personal communication, October 31, 2001) came to tell me of her grandmother's vision of the Virgin Mary. In Galveston's Hurricane of 1900, her grandmother's family fled to the third floor of their house as the water rose almost to that level. Her grandmother prayed the rosary, and the Virgin Mary appeared to her and told her they would be spared. The water then began to recede. 
9. Conversions (like Paul's). According to one account, a Jew had an encounter with Jesus, after which he converted to Christianity and went on to become a bishop (Rankin, 2008, pp. 101-102). A modern account involves an atheist who saw Jesus and then became a believing Christian (Maxwell \& Tschudin, 2005, pp. 104-105). Mark Fox (2008, pp. 41-42) cited a Hindu who had a vision of Jesus and then converted to Christianity.

The following account is from a woman who was worried about the fate of her dead brother because he had not become a Christian. Five months after his death, she reported:

"I looked up off to my right, my brother was there with the Lord! They were life-sized very very real, very solid and distinct and threedimensional. They were very close, shoulder-to-shoulder, and I only saw the upper portion of them. Leon (her brother) was facing me, the Lord was wearing a robe and facing him, and they were both smiling. My brother appeared younger than when he died and looked very healthy. Nothing needed to be said-Leon was with the Lord and that's all I wanted to know." (Guggenheim \& Guggenheim, 1996, p. 309)

This story echoes the great Universalist passage, "And I, when I am lifted up from the earth, will draw all people to myself" [emphasis added] (Jn 12:32).

\section{Veridical Cases}

The validity of an ADC is greatly enhanced when the experience can be verified by others. These "veridical" cases of mystical religious experiences occur when more than one person sees the vision at the same time or when the vision imparts information that would not or could not have been known to the person who experienced the vision (Fox, 2008, pp. 57-77; Maxwell \& Tschudin, 2005, p. 78; Myers, 1903, pp. 40-42).

\section{Aftereffects}

To me, the most impressive aftereffect of any mystical / religious / spiritual experience-including ADCs-is how they have changed people's lives for the better (Hardy, 1997, pp. 101-103; Hay, 1987, p. 157; Hick, 2006, pp. 51, 206; Maxwell \& Tschudin, 2005, pp. 36-44; Yao \& Badham, 2007, p. 45). Mother Teresa heard the voice of Jesus asking her to serve the poor in India (Rankin, 2008, p. 206). When 
Martin Luther King was wavering about his commitment to the civil rights movement, he heard the voice of Jesus giving him reassurance and courage to go on (Marsh, 2005).

The next two 20th-century accounts are from David Parke, a Unitarian Universalist minister. The first occurred after his wife had a stillborn child:

Late at night, under a soft October rain, a Christ-like presence entered my life that night as if to say, 'David, your baby is with God, and you and your bride will recover from this loss, and you will become parents again.' In faith, I saw in my mind's eye my unborn son rising on a sunbeam to Heaven. I never doubted that God in Christ came to me and spoke to me that night. (David Parke, personal communication, January 22, 2010)

His second experience took place the following year when he was a young divinity student at the University of Chicago:

Then mid-way through my first year, the crucified Christ appeared to me in my dormitory room. For those few moments-I do not know for how long-Jesus Christ crucified occupied my entire personal horizon. His tragic visage and piercing eyes penetrated to the bottom of my soul. He did not speak. I did not speak. Although unspoken, the message was clear-'I come from the God of Abraham, Isaac, and Jacob. Your life is your own, but it is also God's. Do not be diverted by self-indulgence and concern for the opinions of others. You are called to minister-and to minister is to suffer as I have suffered. Give yourself to those who come to you in brokenness. Listen to them. Heal them. Love them. You can do less, but more than this you cannot do. I am with you always.' You will understand, friends, that other than my own birth and the birth of my children, this was the most important moment of my life [emphasis added]. (David Parke, personal communication, January 22, 2010)

\section{Conclusion}

Based on the evidence of modern accounts of ADCs of Jesus, other divine beings, and ordinary people, it is apparent that the resurrection appearances of Jesus in the Gospels resemble the modern ones. Modern liberal biblical scholars, such as the Jesus Seminar, see the empty tomb story as a later development (Funk et al., 1998, p. 462).

Recent scholarship into spiritually transformative experiencesincluding ADCs-indicates that they are quite common in the general population in the U.S., Europe, and China (Argyle, 2000, pp. 47-59; Fenwick \& Fenwick, 2008, pp. 120-121; Yao \& Badham, 2007, 
pp. 184-192). Although ordinary people appear to their loved onesusually only one or two-Jesus has continued to appear throughout the ages both to those who love him and to others.

Although ADCs of Jesus, other divine figures, and ordinary people -both ancient and modern-do not prove afterlife, they definitely point to it and show a continuity of experience that is part of the phenomenological reality of humanity. This phenomenon is a source of great comfort to me, and I hope it is to other people who are skeptical of a physical resurrection.

\section{References}

Argyle, M. (2000). Psychology and religion. New York, NY: Routledge.

Bucke, R. M. (1991). Cosmic consciousness. New York, NY: E. F. Dutton. (Original work published 1901)

Fenwick, P., \& Fenwick, E. (2008). The art of dying. New York, NY: Continuum.

Fox, M. (2008) Spiritual encounters with unusual light phenomena: Lightforms. Cardiff, Wales: University of Wales Press.

Funk, R., \& the Jesus Seminar. (1998). The acts of Jesus: The search for the authentic deeds of Jesus. New York, NY: HarperSanFrancisco.

Guggenheim, B., \& Guggenheim, J. (1996). Hello from heaven. New York, NY: Bantam.

Hardy, A. (1997). The spiritual nature of man. Oxford, England: The Religious Experience Research Centre. (Original work published 1979)

Hargrove, T. (1995) Long march to freedom. New York, NY: Ballantine Books.

Hay, D. (1987). Exploring inner space: Scientists and religious experience. London, England: Mowbray.

Hick, J. (2006) The new frontier of religion and science: religious experience, neuroscience, and the transcendent. New York, NY: Palgrave Macmillian.

Hyslop, J. H. (1908). Psychical research and the resurrection. London, England: T. Fisher Unwin.

Johnson, L. T. (1998). Living Jesus: Learning the heart of the gospel. New York, NY: HarperCollins.

Kalish, R. A., \& Reynolds, D. K. (1973) Phenomenological reality and post-death contact. Journal for the scientific study of religion, 12,2, 209-221.

Marsh, C. Receiving the call. Retrieved from: http://www.beliefnet.com/story/159/ story_15941.html

Maxwell, M., \& Tschudin, V. (2005). Seeing the invisible. Ceredigion, Wales: Religious Experience Research Centre. (Original work published 1990)

Migliore, V. (2009) A measure of heaven. Folsom, CA: Blossom Hill Books.

Myers, F. W. H. (1915). Human personality and its survival of bodily death. London, England: Logmans, Green. (Original work published 1903)

Newsweek. (2009). God's miraculous makeover. Newsweek, 153(5), 12.

Otto, R. (1950). The idea of the holy. New York, NY: Oxford University Press. (Original work published 1917)

Rankin, M. (2008). An introduction to religious and spiritual experience. London, England: Continuum International. 
Sparrow, G. S. (1995) I am with you always: True stories of encounters with Jesus. New York, NY: Bantam Books.

White, L. M. (2004) From Jesus to Christianity. New York, NY: HarperSan Francisco.

Wiebe, P. H. (1997). Visions of Jesus: Direct encounters from the New Testament to today. New York, NY: Oxford.

Yao, X., \& Badham, P. (2007) Religious experience in contemporary China. Cardiff, Wales: University of Wales Press. 